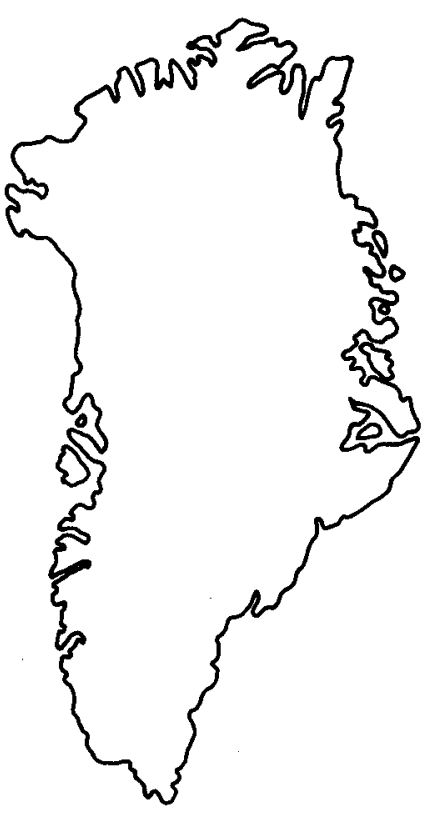

\title{
Late Bathonian to Early Oxfordian dinoflagellate cyst stratigraphy of Jameson Land and Milne Land, East Greenland
}

\author{
Morten Smelror
}

\begin{abstract}
The stratigraphic distribution of Upper Bathonian to early Middle Oxfordian dinoflagellate cysts from localities in Jameson Land and in Milne Land, East Greenland, is evaluated. Using the range of selected species, their earliest appearances and/or extinction, six dinoflagellate cyst zones and five subzones are proposed for the upper Middle and lower Upper Jurassic succession of central East Greenland. The proposed zonation scheme is correlated with the ammonite zonation of the investigated interval. Two new species, Chytroeisphaeridia grossa sp. nov. and Escharisphaeridia laevigata sp. nov. are formally described.
\end{abstract}

M. S., Continental Shelf and Petroleum Technology Research Institute Ltd., P.O. Box 1883 Jarlesletta, N-7001 Trondheim, Norway.

Jurassic dinoflagellate cysts were first described from East Greenland by Sarjeant (1972), who recorded 51 species in two samples from the Vardekløft and Olympen Formations of Jameson Land. The results of a more extensive palynological study were published by Fensome (1979) who described 74 species of dinoflagellate cysts and acritarchs from Bajocian to Volgian strata. An important palynostratigraphic contribution was given by Piasecki (1980) who outlined the stratigraphic distribution of 95 dinoflagellate cyst species through the Upper Callovian to Volgian sequence of Milne Land. Piasecki proposed a dinoflagellate cyst zonation scheme which he correlated with the Jurassic ammonite zonation of East Greenland. Additional data on the dinoflagellate cyst stratigraphy of the lower part of the Hareelv Formation of Jameson Land have been given by Poulsen (1985). Information on dinoflagellate cyst floras from the Middle and Upper Jurassic of Jameson Land is also found in Lund \& Pedersen (1985). Data on Jurassic pollen and spores from East Greenland are published by Muir (in Sarjeant, 1972) and Lund \& Pedersen (1985).

The objective of this study has been to provide additional information on upper Middle and lower Upper Jurassic dinoflagellate cyst floras from Jameson Land and Milne Land, and to synthesise the previously published data on upper Middle and lower Upper Jurassic dinoflagellate cyst stratigraphy of East Greenland. 


\section{Geological framework}

The Mesozoic rocks in central East Greenland are exposed in a basin $800 \mathrm{~km}$ long and a maximum of $140 \mathrm{~km}$ wide, which contains an up to $5 \mathrm{~km}$ thickness of sediments (Surlyk, 1978). The principal area of occurrence is in Jameson Land - Milne Land (fig. 1), the succession in Jameson Land being the most complete and best known (Surlyk et al., 1973). The Jurassic basin was formed as a north-south trending graben system, which opened up from south to north, and thus was transgressed in consecutively later Jurassic times in a northward direction (Surlyk, 1978). The initial Jurassic transgression of the Jameson Land area took place in the Pliensbachian, while the irregular basement surface of Milne Land (bordering the Jameson Land basin to the west) was inundated for the first time in the Late Bathonian (Callomon \& Birkelund, 1980). By this time fully marine conditions were established on the Jameson Land area (Surlyk, 1978). A general map of Middle Jurassic (Bathonian-Callovian) palaeogeography and facies of East Greenland is shown on fig. 2.

Descriptions of the stratigraphy of the Jurassic and Lower Cretaceous sediments of Jameson Land are given by Surlyk et al. (1973) and Surlyk \& Zakharov (1982). Descriptions of the upper Middle and Upper Jurassic stratigraphy of Milne Land are given by Callomon \& Birkelund (1980). Comparisons of the Bathonian to Oxfordian deposits of northern Jameson Land and the east coast of Milne Land in relation to the ammonite zonation are shown in fig.

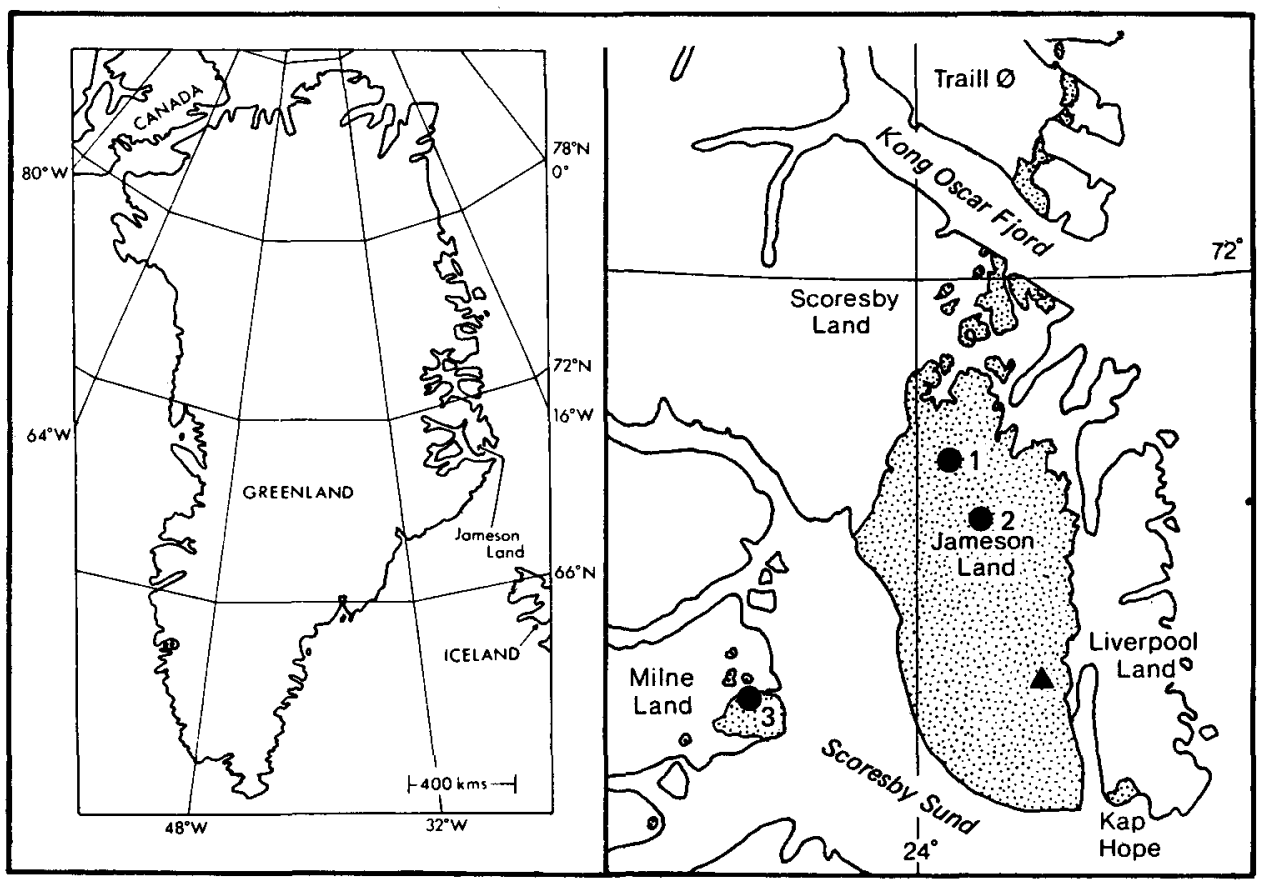

Fig. 1. Map of Milne Land and Jameson Land, East Greenland, showing the location of the studied sections. (Black dots: sections studied by the present author, black triangle: section studied by Poulsen, 1985.) 1: Fossilbjerget, 2: Olympen, 3: Kosmocerasdal. 


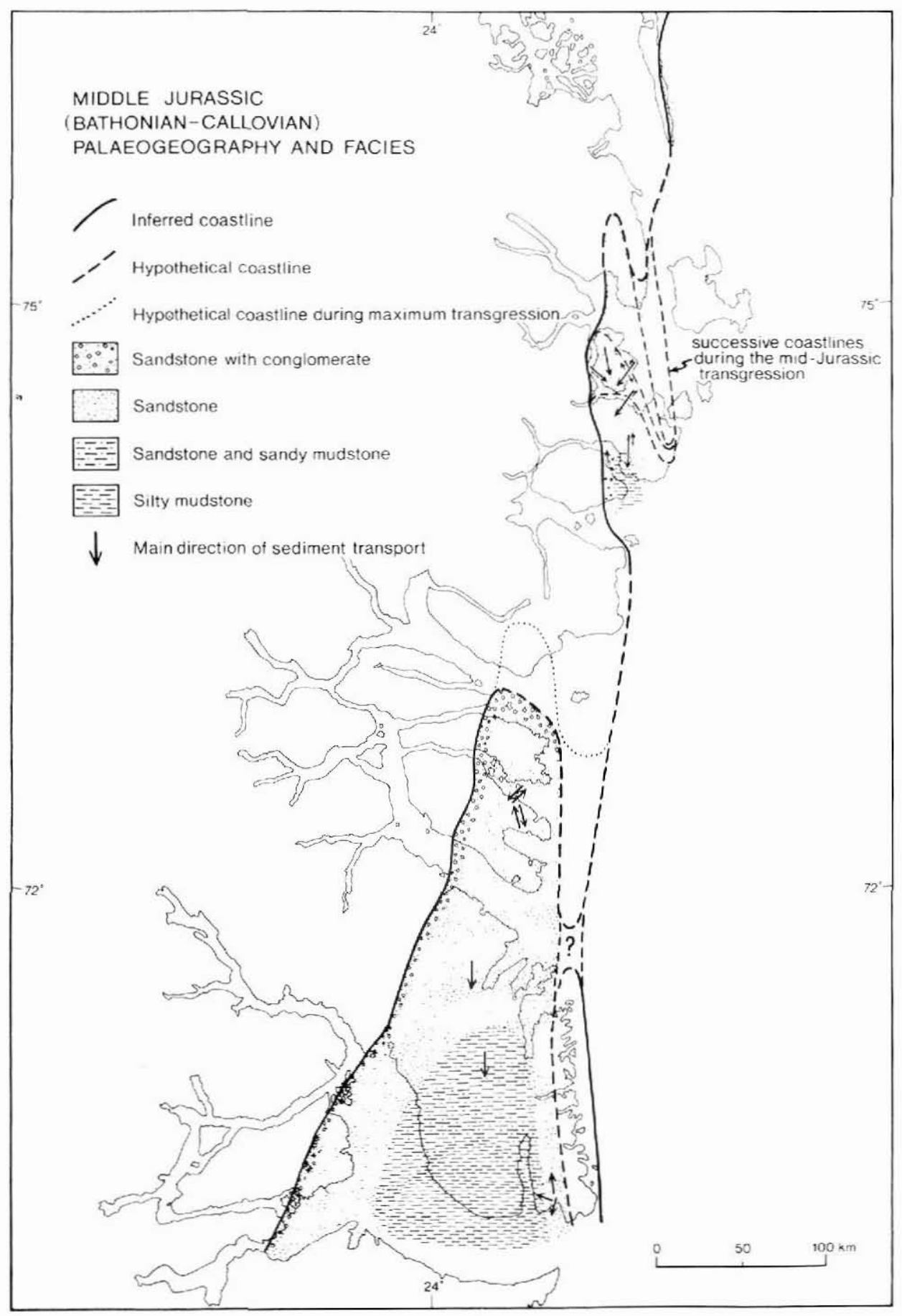

Fig. 2. Middlc Jurassic palaeogeography and facies of East Greenland (From Surlyk, 1977). 
3. As shown in fig. 3, the present study deals with material from the Fossilbjerget Member (Vardekløft Formation) and the lower Olympen Formation in Jameson Land, and from the Kosmocerasdal Member (Kap Leslie Formation) in Milne Land. Previously published data from the lower part of the Hareelv Formation in Jameson Land are included in the biostratigraphic synthesis.

The Fossilbjerget Member (Vardekløft Formation) in Jameson Land comprises silty, micaceous, non-argillaceous shales with subordinate fine-grained sandstone horizons, the lower part being more sandy than the upper part. Numerous horizons with phosphatic nodules, concretionary, indurated silt or fine-sand bodies, and calcareous concretions occur throughout the formation (Surlyk et al., 1973). Many horizons are extremely fossiliferous, ammonites and belemnites dominating, and a number of trace fossil assemblages occur through the whole sequence. In the upper part fossil wood is widespread, including large petrified tree-trunks.

The upper boundary of the Vardekløft Formation (in northern Jameson Land) is marked by a sharp change in sedimentation to light sandstones of the Olympen Formation. The Olympen Formation shows a characteristic tripartite development. The lower unit consists of medium-grained, light-coloured, well sorted sands or massive sandstones, intercalated with subordinate laminated, dark, silty shales or fine laminated sands. The middle unit consists of dark silty shales passing upwards into gradually more sandy shales. The upper unit is developed as massive, cliff-forming, medium to coarse-grained, well-sorted sandstones with subordinate intercalations of silty shales (Surlyk et al., 1973).

The Hareelv Formation is composed of black and grey shales with large irregular lenses

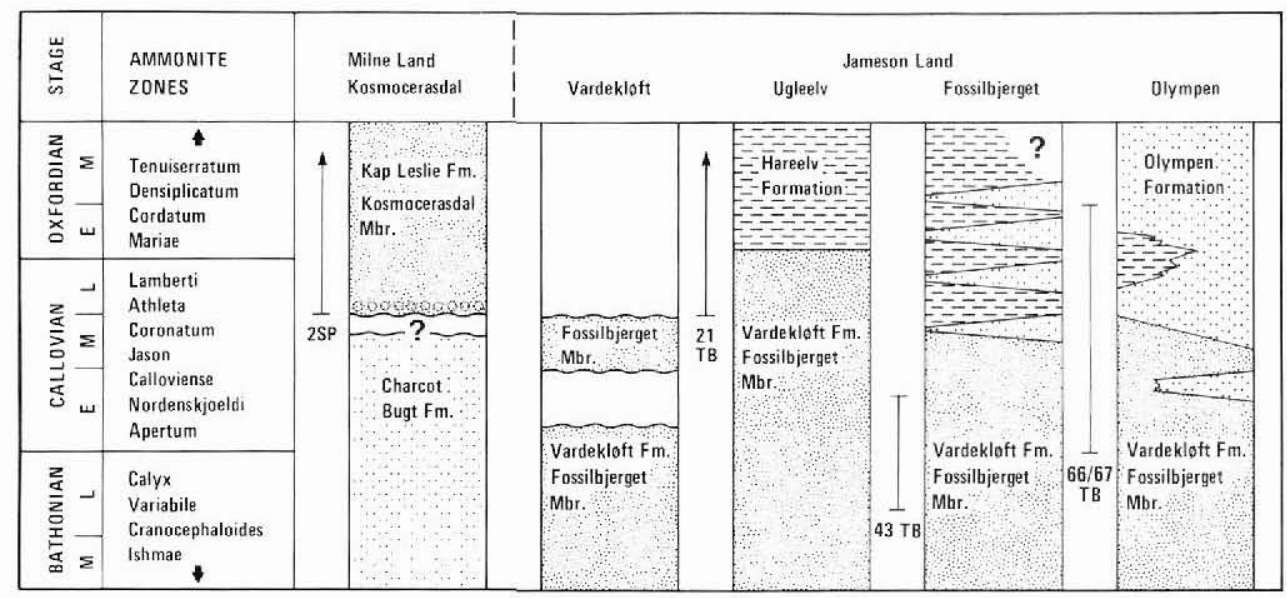

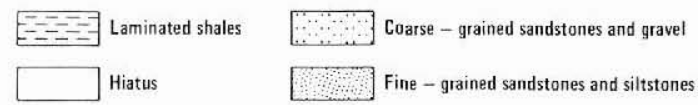

Fig. 3. Comparisons of the Middle Bathonian to Lower Oxfordian successions in Milne Land and Jameson Land. The intervals 2SP on Milne Land, and 43 TB and 66-67 TB on Jameson Land are examined during this present study. (Compiled with data from Surlyk et al., 1973; Piasecki, 1980; Callomon \& Birkelund, 1980; Poulsen 1985.) 
and layers of yellow sandstones (Surlyk et al., 1973). The shales are normally fine-grained, but also some more sandy horizons occur. The boundaries between the shales and sandstones are always sharp. The sandstones are well-sorted, medium-grained and rich in mica and sometimes glauconite. Silicified wood and charcoal are very common in the sandstones and often form the cores of the concretions found in the shales. Rare ammonites are recorded in thin hard glauconitic sandstones.

The Kosmocerasdal Member of the Kap Leslie Formation in Milne Land consists of soft, grey, bioturbated sandy siltstone, rich in plant debris. The otherwise monotonous sequence is broken by a series of concretionary levels ranging from well-spaced lenticles of merely indurated shale to large rounded yellow or rusty-weathering doggers of fine-grained sandstone locally fused into continuous beds (Callomon \& Birkelund, 1980). The Kosmocerasdal Member is approximately laterally time-equivalent to the Olympen Formation in northern Jameson Land (see fig. 3).

\section{Material and methods}

The samples investigated in the present study are from Fossilbjerget and Olympen in northern Jameson Land (figs 1, 2), and from Kosmocerasdal in Milne Land (see location map fig. 1 in Callomon \& Birkelund, 1980 and the present figs 1, 2). The material from northern Jameson Land was collected by T. Birkelund (profiles 66-67 TB and 43 TB), and the samples from Milne Land by S. Piasecki (profile 2SP).

From the section at Fossilbjerget (profile 43 TB), six samples covering the interval from the Variabile Zone to the Nordenskjoeldi Zone of the Vardekløft Formation have been examined (i.e. from the Fossilbjerget Member). From the section at Olympen (profile 66-67 TB), eighteen samples of the Vardekløft Formation and three samples of the Olympen Formation have been analysed. These samples range in age from the Apertum Zone (earliest Callovian) to the Mariae Zone (earliest Oxfordian).

From the Kosmocerasdal section in Milne Land (profile 2SP), thirteen samples from the Kap Leslie Formation (Kosmocerasdal Member) have been included in this study. The samples range from Callovian to the Early Oxfordian Cordatum Zone.

All sample numbers (GGU prefix) refer to the sample collection of the Geological Survey of Greenland, Copenhagen, Denmark; details on stratigraphic level and lithology of the investigated samples can be obtained from GGU. The samples were prepared by standard palynological techniques at the Continental Shelf and Petroleum Technology Research Institute (in Trondheim, Norway). Slides and SEM-stubs with the illustrated specimens are lodged in the collections of the Geological Museum, Copenhagen (refered to by MGUH numbers).

\section{Remarks on dinoflagellate cyst frequency distribution}

All samples investigated yielded relatively abundant, mostly moderately to well preserved, palynomorph assemblages. Terrestrially derived organic material dominates the overall palynofacies in all examined intervals, with gymnospermous pollen (in some samples Cerebropollenites spp. and Callialasporites) and bisaccate pollen dominating among the palynomorphs. Dinoflagellate cysts are numerically subordinate to pollen in all examined samples. The number of marine species recorded in each sample varies between 3 and 21, 
with the highest number of species recorded from the Calloviense and Nordenskjoeldi ammonite Zones.

Several of the recorded dinoflagellate cyst species show characteristic peaks in their abundance at various intervals. In the Upper Bathonian of Jameson Land, a peak in the abundance of Lacrymodinium warrenii has been observed in the Calyx Zone at the Fossilbjerget section. Apart from this species, no other marine taxa appear to be prominent in the Upper Bathonian - Lower Callovian (Variabile Zone - Nordenskjoeldi Zone) interval of the Fossilbjerget Member at Fossilbjerget. In the Lower Callovian strata at Olympen a peak in the abundance of Endoscrinium galeritum has been observed in one sample from the Apertum Zone. Chlamydophorella ectotabulata appears to be most frequent in samples examined from the Nordenskjoeldi Zone. Of further note are the peaks in the frequency distribution of Chytroeisphaeridia grossa sp. nov. within the Early Callovian Nordenskjoeldi and Calloviense Zones. This species also shows a relatively high abundance in the earliest sample of the earliest Oxfordian Mariae Zone at Olympen. The lowermost Oxfordian interval of the Olympen Formation is here further characterized by distinct peaks in the abundance of Rhynchodiniopsis cladophora and Liesbergia scarburghensis.

In the Late Callovian Athleta and Lamberti Zones at Kosmocerasdal in Milne Land, observable peaks in the abundance of Gonyaulacysta jurassica, Escharisphaeridia laevigata sp. nov., Chlamydophorella ectotabulata, Rhynchodiniopsis cladophora, Ctenidodinium continuum and Mendicodinium groenlandicum are seen at various horizons. Peaks in the abundance of Mendicodinium groenlandicum within the latest Callovian have earlier been observed within the Hareelv Formation on Jameson Land (Poulsen, 1985) and elsewhere in North-West Europe (Riley \& Fenton, 1982). Furthermore this species is reported to have its highest abundance at the Callovian - Oxfordian boundary in Kong Karls Land (Smelror, in press) and in the Swiss Jura (Berger, 1986).

The Early Oxfordian Cordatum Zone is at Kosmocerasdal characterized by the incoming of relatively abundant Rigaudella aemula, and further by a relative increase in the abundance of Liesbergia scarburghensis compared with the Upper Callovian - lowermost Oxfordian interval below. Based on material from the Upper Jurassic of Great Britain and the central part of the North Sea, Raynaud (1978) noted a similar peak in the abundance of $L$. scarburghensis (registered as Gonyaulacysta areolata) within the Cordatum ammonite Zone. Riley \& Fenton (1982), Woollam \& Riding (1983) and Berger (1986), however, pointed out a characteristic increase in the abundance of this species near the base of the earliest Oxfordian Mariae Zone. Smelror (in press) also observed a distinct peak in the abundance of the species within the lowermost Oxfordian in Kong Karls Land, Svalbard.

\section{Dinoflagellate cyst stratigraphy: discussion}

There are several publications on European Jurassic dinoflagellate cyst biostratigraphy established in sequences with ammonite control, i.e. the ranges of cyst taxa are defined in terms of ammonite zones. The most important contributions with respect to the stratigraphic interval included in this present study are those published by Riley \& Fenton (1982) and Woollam \& Riding (1983). The contribution of Woollam \& Riding (1983) also includes a review and correlations with previously published dinoflagellate cyst zonations within the late Triassic to early Cretaceous. Comparisons of the dinoflagellate cyst zonation schemes proposed for the late Middle and early Late Jurassic by Riley \& Fenton (1982) and Woollam 


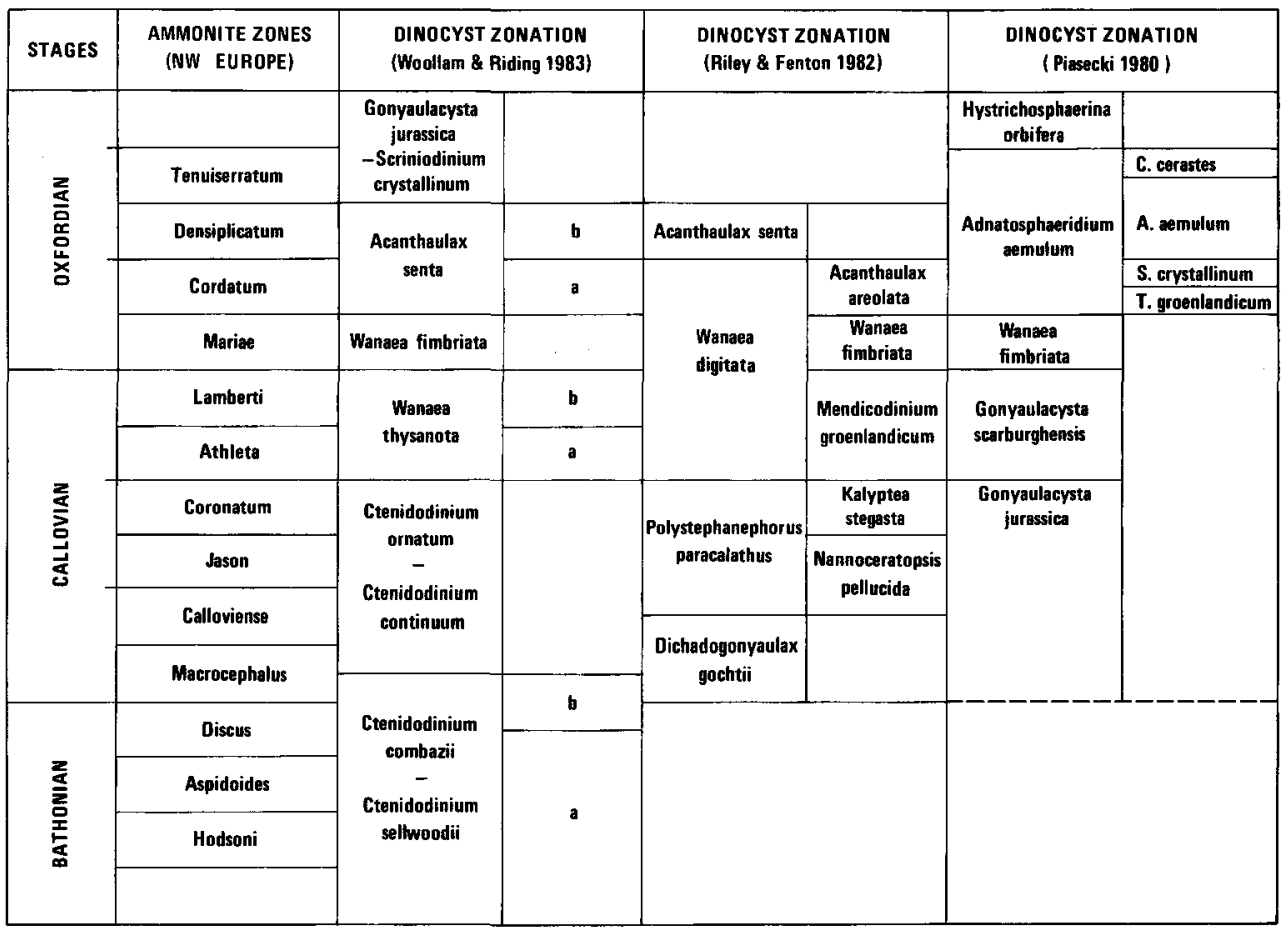

Fig. 4. Comparisons of the dinoflagellate cyst zonation schemes proposed for the upper Middle and lower Upper Jurassic by Riley \& Fenton (1982), Woollam \& Riding (1983) and Piasecki (1980).

\& Riding (1983) are shown in fig. 4, which also includes a correlation with the dinoflagellate cyst zonation of the East Greenland Jurassic proposed by Piasecki (1980).

A detailed dinoflagellate cyst stratigraphy of the Middle Callovian to Volgian on Jameson Land and Milne Land has earlier been proposed by Piasecki (1980). Middle and Upper Callovian strata were dividied into the Gonyaulacysta jurassica Zone covering the Jason and Coronatum ammonite Zones, and the Gonyaulacysta scarburghensis Zone (G. scarburghensis = Acanthaulax scarburghensis) covering the Late Callovian Athleta and Lamberti Zones. Lower and Middle Oxfordian strata were divided into the Wanaea fimbriata Zone, corresponding to the earliest Oxfordian Mariae ammonite Zone, and the Adnatosphaeridium aemulum Zone ( $A$. aemulum $=$ Rigaudella aemula) covering the Cordatum, Densiplicatum and partly the Tenuiserratum Zones. The Adnatosphaeridium aemulum dinocyst Zone was further divided into four subzones.

A list of the dinoflagellate cyst and acritarch species recorded from the Upper Bathonian to the Lower Oxfordian of Jameson Land and Milne Land from the investigated samples is given at the end of this paper. The stratigraphic distribution of these species in the studied sections (2SP in Milne Land and 43 TB and 66-67 TB in Jameson Land) is outlined in figs 5-7. Several of the recorded dinoflagellate cysts and acritarchs occur through the entire studied interval, while several of the other species recorded with a restricted stratigraphic 
distribution are known to have a wider distribution elsewhere. A few important species, however, have limited occurrence and are regarded as being of biostratigraphical importance.

\section{Upper Bathonian - Lower Callovian}

Within the Upper Bathonian and Lower Callovian sequence of East Greenland the dinoflagellate cysts Meiourogonyaulax callomonii, Lacrymodinium warrenii, Kylindrocysta spinosa and Sirmiodinium grossii appear to be usable biostratigraphic markers. According to Sarjeant (1979) Meiourogonyaulax callomonii has its earliest appearance within the Aspidoides ammonite Zone elsewhere in North-West Europe. In East Greenland this species occurs in the time-equivalent Variabile Zone, and ranges into lower Upper Callovian strata. In the material from East Greenland Lacrymodinium warrenii occurs within the Upper Bathonian and Lower Callovian, ranging from the Variabile Zone to the Calloviense Zone.

Kylindrocysta spinosa is most prominent within the Late Bajocian to the Middle Bathonian of the British Jurassic, but according to Woollam \& Riding (1983) this species may range into the latest Bathonian Discus Zone. In East Greenland this species is observed within the Late Bathonian and the earliest Callovian Apertum Zone, and the extinction of this species within this ammonite zone appears to be of biostratigraphic significance.

Sirmiodinium grossii is known to have its earliest occurrence within the Discus Zone elsewhere in North-West Europe (Sarjeant, 1979; Woollam \& Riding 1983), and the species also first appears within the time-equivalent latest Bathonian Calyx Zone in East Greenland. Woollam \& Riding (1983) used the first appearance of this species to define the base of their Ctenidodinium combazii - Ctenidodinium sellwoodii ( $\mathrm{Ccb} / \mathrm{Cs})$ Subzone b. Woollam \& Riding (1983) further used the extinction of the key species Ctenidodinium combazii to define the upper boundary of their $\mathrm{Ccb} / \mathrm{Cs}$ Subzone $\mathbf{b}$. This species has so far not been recorded from East Greenland. Fensome (1979) described the new species Ambonosphaera calloviana from the Calloviense ammonite Zone of the Fossilbjerget Member in northern Jameson Land. In the present material this species has been recorded from the Calloviense Zone and undefined Middle to Upper Callovian deposits at the Olympen section and from strata of the Athleta Zone of the Kosmocerasdal section. The earliest incoming of this species might serve as a reliable biostratigraphic marker for the Calloviense Zone. Berger (1986) observed the last occurrence of Ambonosphaera calloviana to be within the Late Callovian Athleta Zone in the Berner Jura, Switzerland. This species has also been recorded within the Athleta Zone at the Kosmocerasdal section in Milne Land.

Piasecki (1980) used the earliest occurrence of Gonyaulacysta jurassica to define the base of his Gonyaulacysta jurassica Zone. The upper boundary was defined by the first appearance of Liesbergia scarburghensis. According to Piasecki the age of the zone was Early and Middle Callovian. In the range chart presented by Raynaud (1978) the earliest incoming of Gonyaulacysta jurassica was placed at the base of the earliest Callovian Macrocephalus Zone. In the present material this species has been recorded from the Apertum to the Mariae Zones at Olympen. However, this species has been recorded from Upper Bathonian deposits elsewhere in North-West Europe (Herngreen \& De Boer, 1978; Fenton et al., 1980; Davey \& Riley, 1978; Herngreen et al., 1983). 


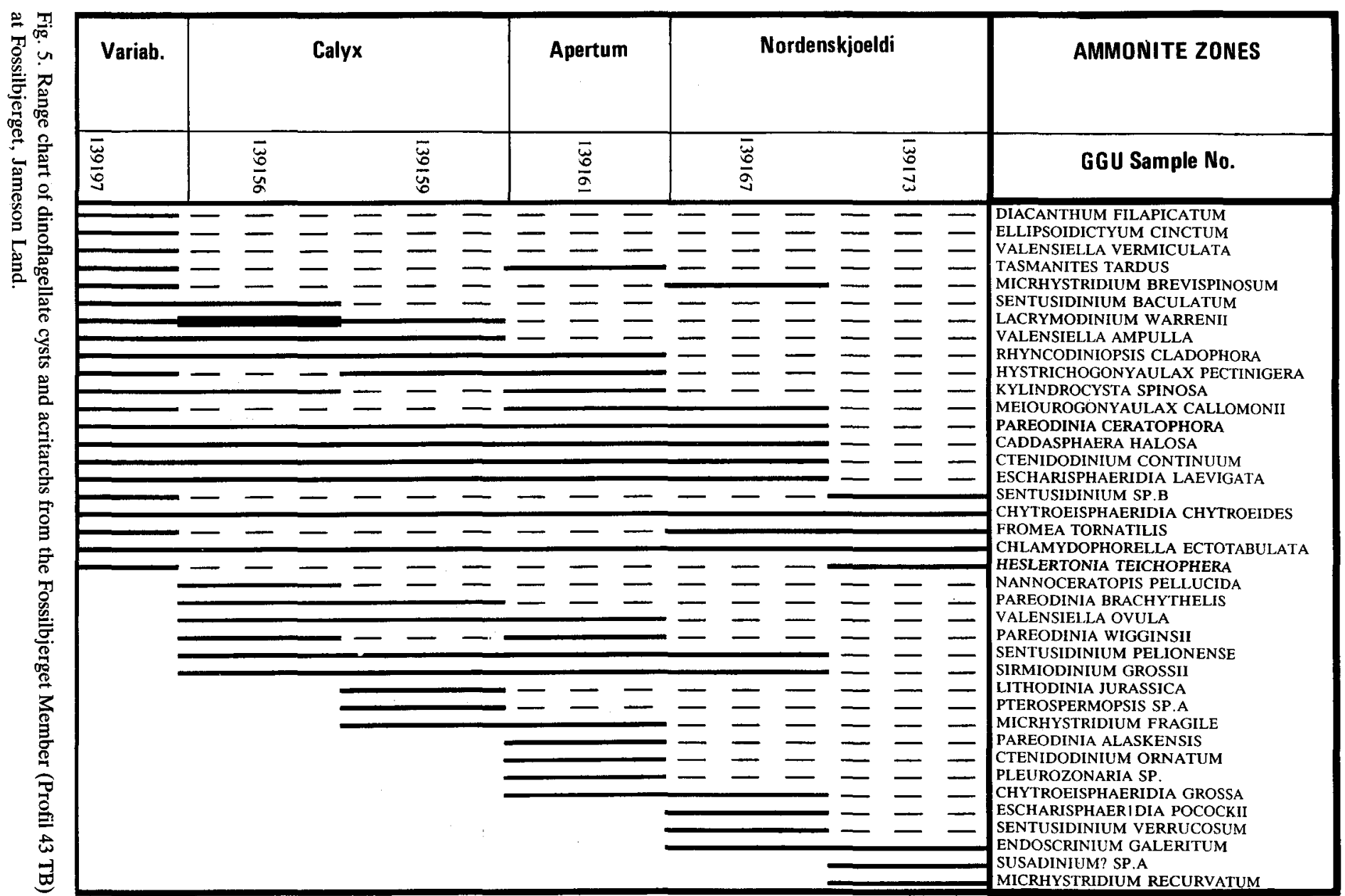




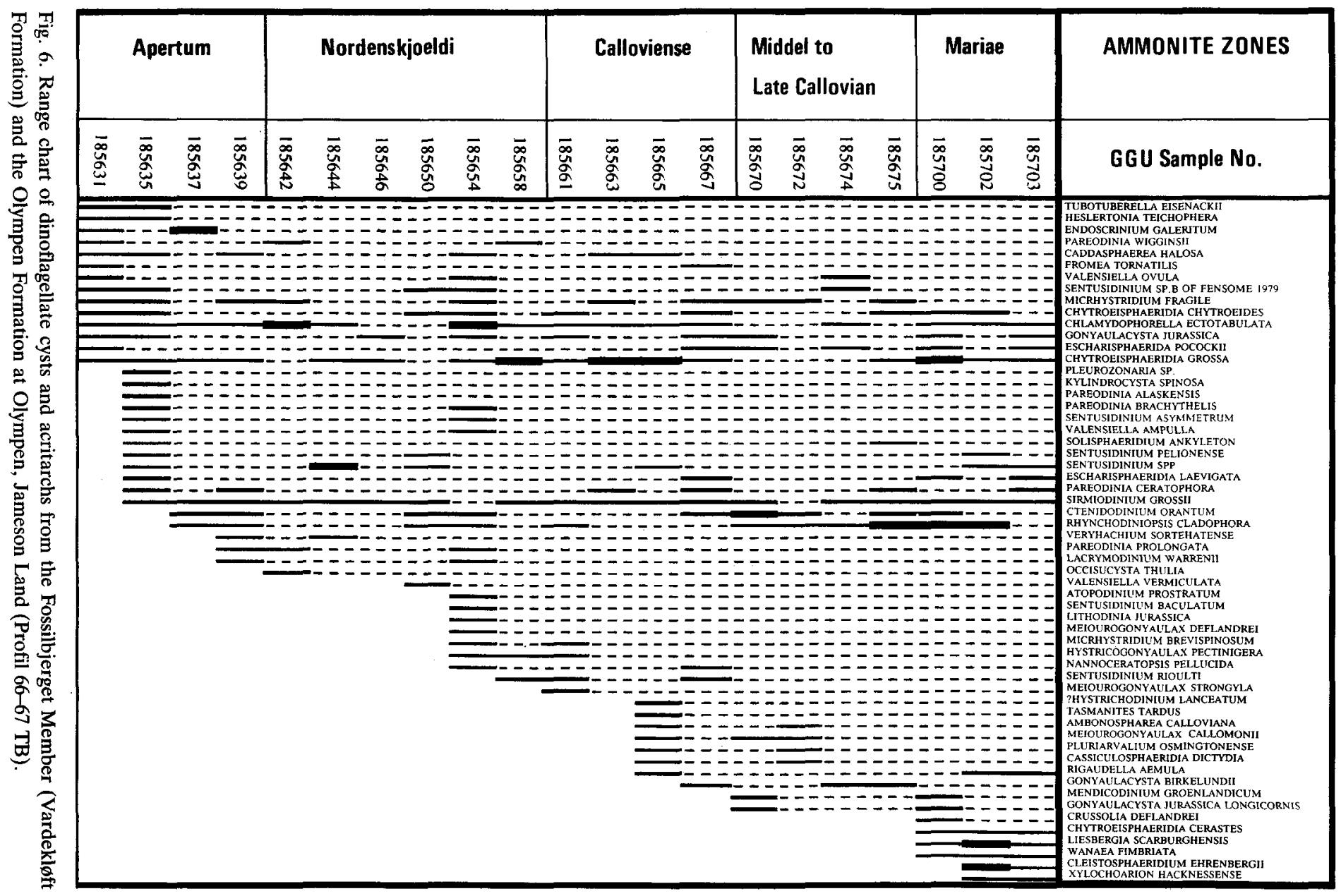




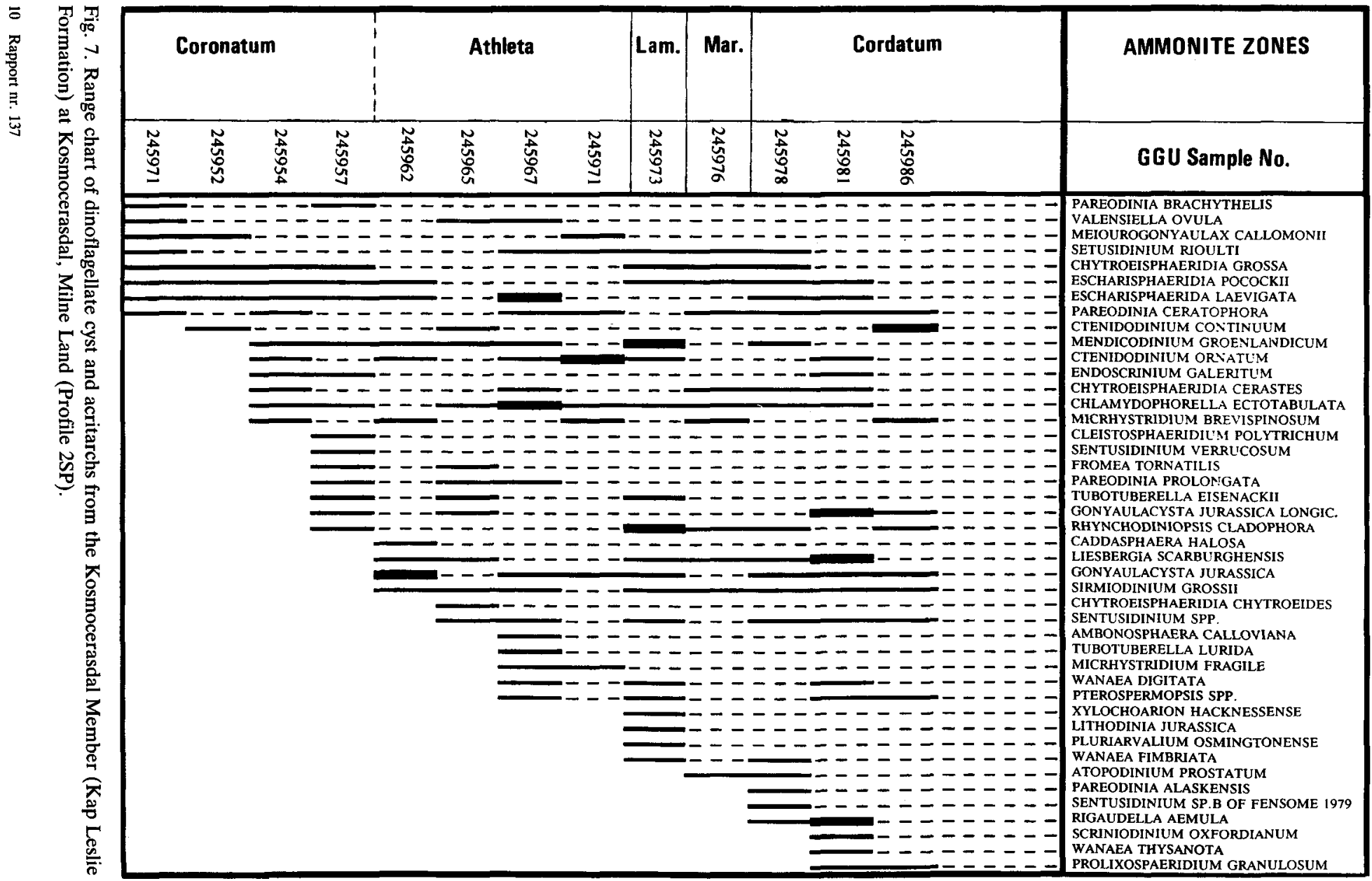




\section{Middle Callovian}

The zonation schemes presented by Riley \& Fenton (1982) and Woollam \& Riding (1983) included both the late Early and the Middle Callovian within one single dinoflagellate cyst zone, i.e. the Polystephanephorus paracalathus Zone (Riley \& Fenton, 1982) and the Ctenidodinium ornatum - Ctenidodinium continuum Zone (Woollam \& Riding, 1983) respectively. Based on the present palynostratigraphic data it is not possible to give any further subdivision of this interval. Woollam \& Riding (1983) used the earliest appearance of Wanaea thysonata to define the base of their Wanaea thysonata Zone. The base of this zone is equivalent to the base of the Athleta Zone, i.e. the base of the Late Callovian. Within the present material from East Greenland only a single specimen of Wanaea thysonata has been recorded from the Cordatum Zone of the Kosmocerasdal section, Milne Land.

Riley \& Fenton (1982) defined their Kalyptea stegasta Subzone within the interval from the earliest appearance of Wanaea digitata to the earliest incoming of Atopodinium prostatum. The Kalyptea stegasta Subzone is time-equivalent to the Coronatum ammonite Zone, i.e. late Middle Callovian. From East Greenland Wanaea digitata has previously been described from the Lower Oxfordian of the Hareelv Formation (Fensome, 1979; Poulsen, 1985 ) in Jameson Land. In the present study this species has been recorded from the Late Callovian Athleta Zone and the Early Oxfordian Cordatum Zone at Kosmocerasdal in Milne Land. A few specimens of Atopodinium prostatum have been recorded from the Nordenskjoeldi Zone at Olympen and the Cordatum Zone at Kosmocerasdal.

\section{Upper Callovian - Lower Oxfordian}

Piasecki (1980) used the earliest appearance of Liesbergia scarburghensis to define the base of his Gonyaulacysta scarburghensis Zone. The top of this dinoflagellate cyst zone was defined by the first occurrence of Wanaea fimbriata. According to Piasecki (1980) the Gonyaulacysta scarburghensis Zone is equivalent to the Athleta and Lamberti Zones in Milne Land. According to Raynaud (1978) L. scarburghensis (recorded as Gonyaulacysta areolata) also occurs from the base of the Athleta Zone elsewhere in North-West Europe, although this species becomes more prominent within the Lamberti Zone and the Early Oxfordian. In East Greenland Liesbergia scarburghensis has previously been recorded from the uppermost Callovian and the Lower Oxfordian of the Hareelv Formation in Jameson Land (Fensome, 1979; Poulsen, 1985). In the present material this species has been recorded from the Athleta, Lamberti, Mariae and Cordatum Zones at the Kosmocerasdal section and from the Mariae Zone at Olympen. According to Riley \& Fenton (1982) the earliest occurrence of Liesbergia scarburghensis is at the base of the Lamberti Zone. The earliest appearance of Liesbergia scarburghensis at the base of the Lamberti Zone was also used by Woollam \& Riding (1983) to define the lower boundary of their Wanaea thysanota Subzone b. The upper boundary of this subzone was defined by the earliest appearance of Wanaea fimbriata. The earliest appearance of Wanaea fimbriata was also used by Riley \& Fenton (1982) and Piasecki (1980) to define the lower boundaries of their Wanaea fimbriata Zones. Although the top of the Wanaea fimbriata Zones presented by Piasecki (1980), Riley \& Fenton (1982) and Woollam \& Riding (1983) were defined differently, all zones were described as equivalent to the earliest Oxfordian Mariae Zone, i.e. the lower boundaries of the zones correspond to the Callovian - Oxfordian boundary. 
In East Greenland Wanaea fimbriata has been recorded from the Mariae Zone of the Olympen Formation in Jameson Land. In Milne Land this species is recorded within the Mariae and Cordatum Zones at the Kosmocerasdal section.

Piasecki (1980) defined the Adnatosphaeridium aemulum Zone as the interval from the first occurrence of Rigaudella aemula to the first occurrence of Hystrichosphaerina orbifera. The age of this zone is equivalent to the Cordatum, Densiplicatum and partly the Tenuiserratum ammonite Zones. In the present study the lower boundary has been recognized within the Cordatum Zone at the Kosmocerasdal section in Milne Land. However, at Olympen in Jameson Land, Rigaudella aemula has been recorded from the Calloviense Zone to the Mariae Zone. Poulsen (1985) further recorded this species within the uppermost Vardekløft Formation and the lower part of the Hareelv Formation at Ugleelv in Jameson Land. Rigaudella aemula is also known from Lower and Upper Callovian deposits elsewhere in North-West Europe (Raynaud, 1978; Riley \& Fenton, 1982; Woollam \& Riding, 1983).

Riley \& Fenton (1982) used the earliest appearance of Leptodinium eumorphum and the extinction of Wanaea digitata to define the lower and upper boundary, respectively, of their Acanthaulax areolata Subzone. The age of this dinoflagellate cyst zone is Early Oxfordian, equivalent to the Cordatum Zone. Leptodinium eumorphum has so far not been recorded from Milne Land, but Poulsen (1985) found that this species first appears near the base of the Hareelv Formation at Ugleelv. Piasecki (1980) recorded the extinction of Wanaea digitata at the top of the Cordatum Zone within the Kap Leslie Formation in Milne Land. Although Leptodinium eumorphum seems not to be common within the Lower Oxfordian of East Greenland, the species can be used to define the Cordatum Zone as suggested by Riley \& Fenton (1982).

\section{Dinoflagellate cyst zonation}

Most of the upper Middle and lower Upper Jurassic dinoflagellate cyst species included in the range chart presented by Riley \& Fenton (1982) and Woollam \& Riding (1983) have also been recorded from the contemporaneous strata in East Greenland. However, several of their key species are apparently missing in East Greenland. Thus the earlier proposed zonation schemes are only partly applicable to the East Greenland successions. The zonation scheme presented by Piasecki (1980) for the succession in Milne Land is considered too broadly defined to serve as an appropriate dinoflagellate cyst zonation of the Upper Bathonian - Middle Oxfordian. Even though most of the dinoflagellate cysts recorded are regarded as relatively long-ranging species a few forms appear to be useful as biostratigraphic markers. The stratigraphic distribution of selected dinoflagellate cysts which appear to have a well-defined range within the Upper Bathonian to the lower Middle Oxfordian of East Greenland is presented in fig. 8.

Based on the appearance, extinction and association of specific dinoflagellate cyst species a new zonation scheme covering the Upper Bathonian - Lower Oxfordian strata of the East Greenland basin is proposed here (fig. 9). The proposed zones are all related to the Late Bathonian - Middle Oxfordian ammonite zonation proposed by Callomon \& Birkelund (1980). The dinoflagellate cyst zonation consists of both range zones and interval zones. 


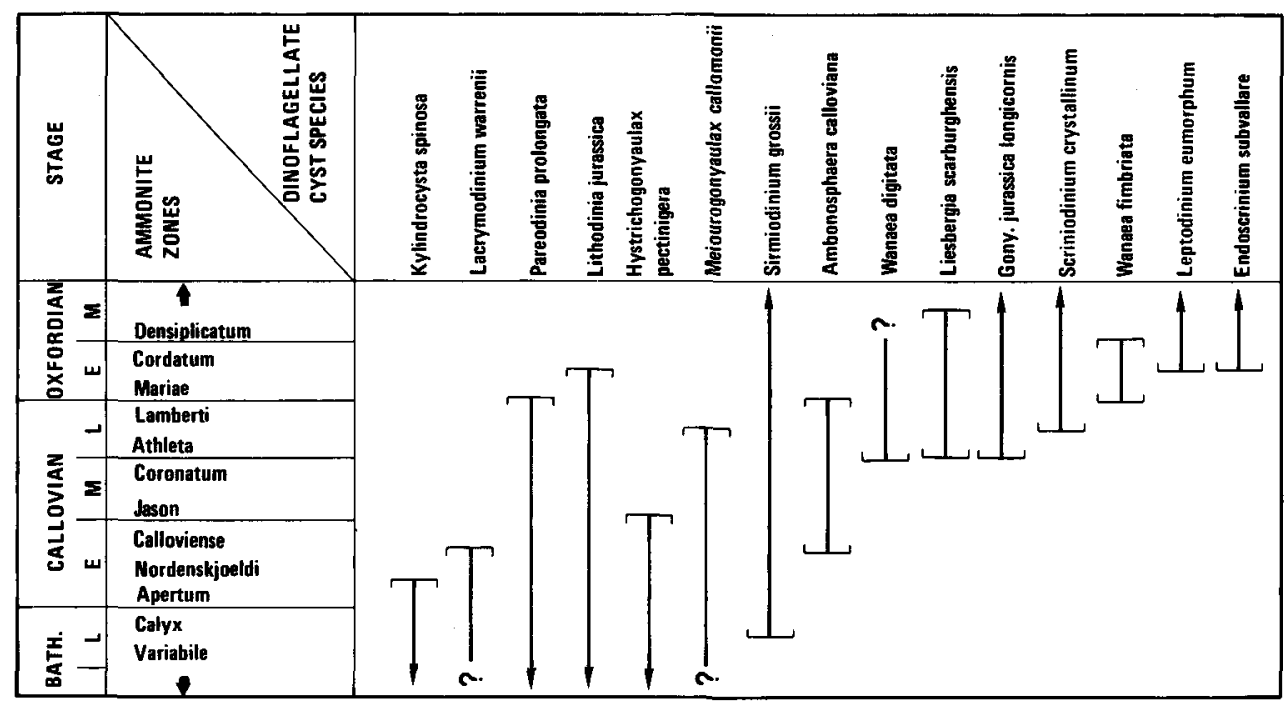

Fig. 8. Range chart of selected dinoflagellate cysts species within Upper Bathonian to lower Middle Oxfordian strata of East Greenland. Based on the present study, including some data from Fensome (1979), Piasecki (1980) and Poulsen (1985).

\begin{tabular}{|c|c|c|c|}
\hline$\underset{5}{\frac{5}{5}}$ & AMMONITE ZONES & \multicolumn{2}{|c|}{ DINOFLAGELLATE CYST ZONES } \\
\hline \multirow{4}{*}{ ن } & 4 & & \\
\hline & \multirow{3}{*}{$\begin{array}{l}\text { Densiplicatum } \\
\text { Cordatum } \\
\text { Mariae }\end{array}$} & \multicolumn{2}{|c|}{ Liesbergia scarburghensis } \\
\hline & & \multirow{2}{*}{$\begin{array}{l}\text { Wanaea } \\
\text { fimbriata }\end{array}$} & b \\
\hline & & & a \\
\hline \multirow{5}{*}{ ن } & \multirow{5}{*}{$\begin{array}{l}\text { Lamberti } \\
\text { Athleta } \\
\text { Coronatum } \\
\text { Jason } \\
\text { Calloviense } \\
\text { Nordenskjoeldi } \\
\text { Apertum }\end{array}$} & \multicolumn{2}{|c|}{ Mendicodinium groenlandicum } \\
\hline & & \multicolumn{2}{|l|}{ Wanaea digitata } \\
\hline & & \multicolumn{2}{|c|}{ Ambonosphaera calloviana } \\
\hline & & \multirow{4}{*}{$\begin{array}{l}\text { Lacrymodinium } \\
\text { warrenii }\end{array}$} & $\mathbf{c}$ \\
\hline & & & h \\
\hline \multirow{2}{*}{ 這总 } & \multirow{2}{*}{$\begin{array}{l}\text { Calyx } \\
\text { Variabile }\end{array}$} & & \\
\hline & & & a \\
\hline
\end{tabular}

Fig. 9. Dinoflagellate cyst zonation of the Upper Bathonian - Lower Oxfordian sequence of East Greenland, correlated with the ammonite stratigraphy. 


\section{Lacrymodinium warrenii Zone}

Definition. Interval from the earliest appearance to the local disappearance of Lacrymodinium warrenii and the earliest incoming of Ambonosphaera calloviana.

Age. Base not determined. Recognized within the Variabile, Calyx, Apertum and Nordenskjoeldi ammonite Zones.

Subzone a. Interval from the earliest appearance of Lacrymodinium warrenii to the earliest incoming of Sirmiodinium grossii.

Age. Variabile Zone.

Subzone b. Interval from the earliest incoming of Sirmiodinium grossii to the extinction of Kylindrocysta spinosa.

Age. Calyx and Apertum Zones.

Subzone c. Interval from the extinction of Kylindrocysta spinosa to the local disappearance of Lacrymodinium warrenii and the earliest appearance of Ambonosphaera calloviana.

Age. Nordenskjoeldi Zone.

\section{Ambonosphaera calloviana Zone}

Definition. Interval from the earliest incoming of Ambonosphaera calloviana (and local disappearance of Lacrymodinium warrenii) to the earliest appearance of Liesbergia scarburghensis, Gonyaulacysta jurassica var. longicornis and Wanaea digitata.

Age. Calloviense, Jason and Coronatum Zones.

\section{Wanaea digitata Zone}

Definition. Interval from the earliest appearance of Liesbergia scarburghensis, Gonyaulacysta jurassica var. longicornis and Wanaea digitata, to the extinction of Meiourogonyaulax callomonii (and local earliest incoming of Scriniodinium crystallinum).

Age. Athleta Zone.

\section{Mendicodinium groenlandicum Zone}

Defintion. Interval from the extinction of Meiourogonyaulax callomonii (and local incoming of $S$. crystallinum) to the earliest appearance of Wanaea fimbriata (and extinction of Pareodinia prolongata and Ambonosphaera calloviana). Locally abundant Mendicodinium groenlandicum.

Age. Lamberti Zone. 


\section{Wanaea fimbriata Zone}

Definition. Interval from the earliest appearance of Wanaea fimbriata (and disappearance of Pareodinia prolongata and Ambonosphaera calloviana) to the extinction of Wanaea fimbriata, i.e. range zone of $W$. fimbriata.

Age. Mariae and Cordatum Zones.

Subzone a. Interval from the earliest appearance of Wanaea fimbriata to the earliest incoming of Leptodinium eumorphum (and locally Endoscrinium subvallare).

Age. Mariae Zone.

Subzone b. Interval from the earliest appearance of Leptodinium eumorphum (and locally Endoscrinium subvallare) to the extinction of Wanaea fimbriata.

Age. Cordatum Zone.

\section{Liesbergia scarburghensis Zone}

Definition. Interval from the disappearance of Wanaea fimbriata to the extinction of Liesbergia scarburghensis.

Age. Densiplicatum Zone.

\section{Systematic palynology}

Class Dinophyceae Fritsch, 1935

Order Periodiniales Haechel, 1894

Division Pyrrophyta Pascher, 1914

Class Dinophyceae Fritsch, 1935

Order Peridiniales Haeckel, 1984

Genus Chytroeisphaeridia (Sarjeant) Sarjeant \& Downie, 1965, emend., Davey, 1979

Type species. Chytreisphaeridia chytroeides (Sarjeant) Downie \& Sarjeant, 1965, emend., Davey, 1970.

Chytroeisphaeridia grossa sp. nov.

Figs 10C, E

Holotype. Fig. 10C, MGUH 18.261, GGU sample 185658, England finder ref. R17/1.

Paratype. Fig. 10E, MGUH 18.623, GGU sample 185631, England finder ref. N38/0.

Description. Dinoflagellate cysts approximately spherical in shape, or when flattened appearing more subspherical elongated, possessing one or more arcuate folds. The cysts are single-walled, the autophragm being relatively thick $(1-2.5 \mu \mathrm{m})$. The autophragm is smooth externally and is unstructured internally. The archeopyle is simple, precingular and formed by the loss of just the fourth precingular paraplate (following the Taylor-Evitt notation 

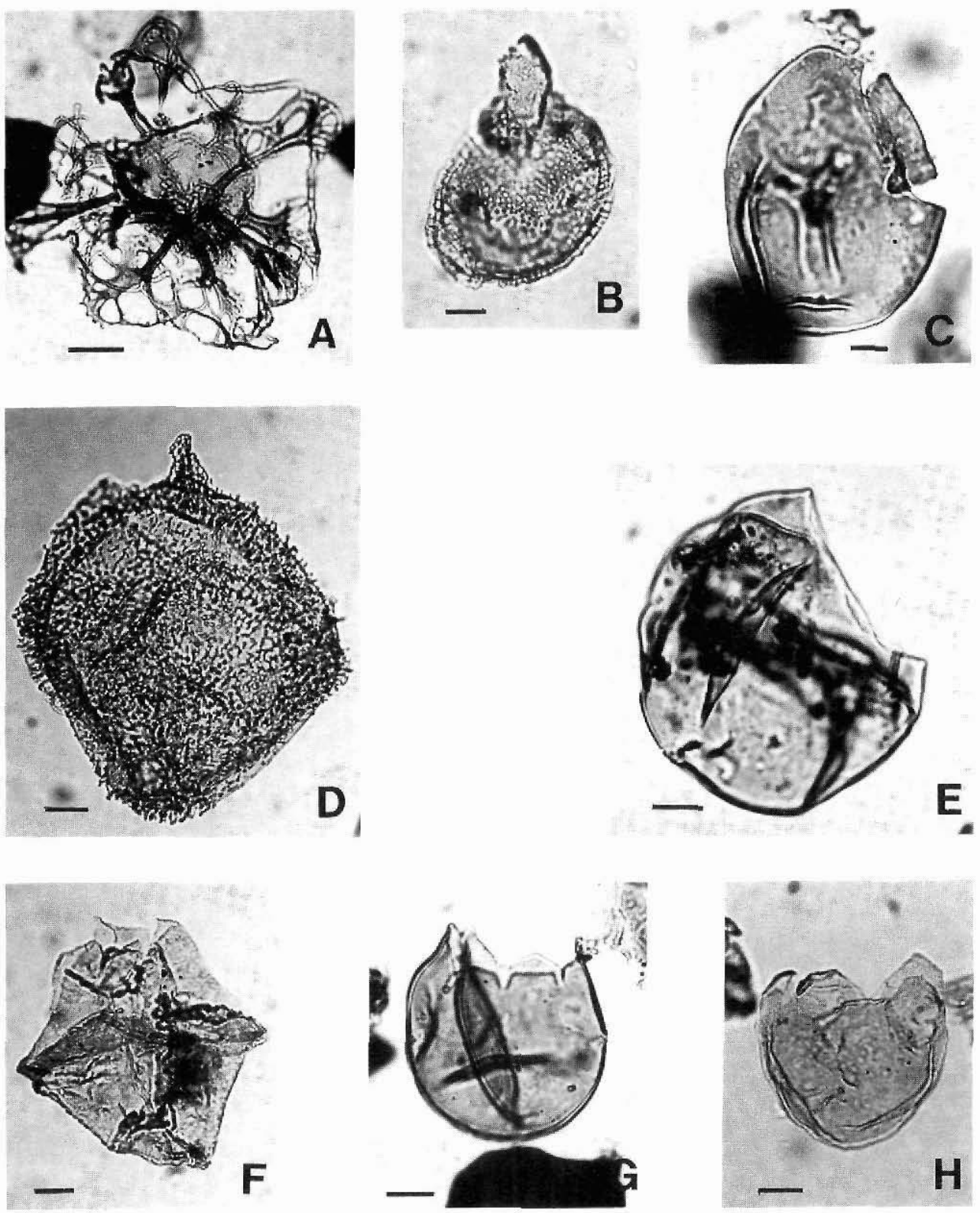

Fig. 10. Upper Middle and lower Upper Jurassic dinoflagellate cysts from East Greenland. Figured specimens can be relocated in permanent slide mounts with the aid of an England Finder using the coordinates given after the comma following the sample numbers. Scale bars represent $10 \mu \mathrm{m}$ in all figures.
A: Rigaudella aemula (Deflandre) Below, 1982. MGUH 18.619, GGU sample 185703, H19/2.
B: Chlamydophorella ectotabulata Smelror, in press. MGUH 18.620, GGU sample 185654, J22/2.
C, E: Chytroeisphaeridia grossa sp. nov. C, holotype, MGUH 18.621, GGU sample 185658, R17/1. E, paratype, MGUH 18.623, GGU sample 185631, N38/0.
D: Liesbergia scarburghensis (Sarjeant) Berger, 1986. MGUH 18.622, GGU sample 185700, E29/3.
F: Atopodinium prostatum Drugg, 1978. MGUH 18.624, GGU sample 245977, V27/2.
G, H: Escharisphaeridia laevigata sp. nov. G, holotype, MGUH 18.625, GGU sample 185700, U32/1. H, paratype, MGUH 18.626, GGU sample 185700, K35/2. 
system; i.e. the third Kofoidian precingular paraplate). The operculum is free and has a tapering hexagonal shape.

Dimensions. Cyst diameters range between 65 and $105 \mu \mathrm{m}$ (20 specimens measured).

Type stratum and locality. Vardekløft Formation, Fossilbjerget Member, Calloviense Zone, at Olympen, northern Jameson Land.

Occurrence. Callovian and Lower Oxfordian of Jameson Land and Milne Land, East Greenland. According to Davey (1979) the stratigraphic range of this species is from Bathonian to Oxfordian. In the North Sea Basin it is particularly characteristic of the Callovian (Davey, 1979).

Remarks. The overall character of Chytroeisphaeridia grossa sp. nov. is similar to Chytroeisphaeridia chytroeides (Sarjeant) Sarjeant \& Downie, 1965, but is considerably larger (in general 35-50 $\mu \mathrm{m}$ larger in cyst diameters) and appears more thick-walled.

\section{Genus Escharisphaeridia Erkmen \& Sarjeant, 1980}

Type species. Escharisphaeridia pocockii (Sarjeant) Erkmen \& Sarjeant, 1980.

Escharisphaeridia laevigata sp. nov.

Figs 10G, H

Holotype. Fig. 10G, MGUH 18.625 GGU sample 185700, England finder ref. U32/1.

Paratype. Fig. 10H, MGUH 18.626, GGU sample 185700, England finder ref. K35/2.

Description. Dinoflagellate cysts generally subspherical in outline, occasionally appearing more ovoidal in shape. The cyst wall is composed of only one layer. The autophragm is smooth, i.e. laevigate with no kind of ornamentation visible even when examined with scanning electron microscopy at high magnifications. Evidence of paracingulum or parasulcus has not been observed, and the only indication of paratabulation is expressed by the apical archeopyle and accessory archeopyle sutures, suggesting the presence of 4 apical and 6 precingular paraplates. A sulcal notch formed where $1 u$ extends toward the paracingulum to meet $a i$ is a typical feature. Specimens with the operculum in place have not been observed, but the shape of the archeopyle indicates that the archeopyle is of type (4A).

Dimensions. Length $36-53 \mu \mathrm{m}$, width $30-41 \mu \mathrm{m}$ (19 specimens measured).

Type stratum and locality. Olympen Formation, Lower Oxfordian at Olympen northern Jameson Land.

Occurrence. Upper Bathonian - Lower Oxfordian strata of southern France, England, East Greenland, Svalbard and Franz Josef Land (Arctic U.S.S.R.). 
Remarks. Escharisphaeridia laevigata sp. nov. appears similar to the specimens illustrated as Escharisphaeridia sp. from the Bathonian Stage type area in South-West England by Riding et al. (1985, pl. V, fig. 8) and to the specimens illustrated as Dinocyst sp. A from the Callovian - Oxfordian of the East Midlands, England, by Woollam (1980, pl. 1, figs 1, 4). Escharisphaeridia laevigata sp. nov. is conspecific with Escharisphaeridia sp. A of Smelror (in press) described from Kong Karls Land, Svalbard.

\section{Genus Liesbergia Berger, 1986}

Type species. Liesbergia liesbergensis Berger,1986.

\section{Liesbergia scarburghensis (Sarjeant) Berger, 1986}

Fig. 10D

1961 'Gonyaulax areolata' Sarjeant, pp. 95-97, pl. 13, fig. 13, text-fig. 5.

1964 Gonyaulacysta scarburghense Sarjeant, pp. 472-473.

1978 Gonyaulacysta areolata Raynaud, p. 396, pl. 2, fig. 7.

1978 Gonyaulacysta areolata Davey \& Riley, pl. 1, fig. 1.

1978 Gonyaulacysta areolata Thusu, pl. 9, figs 4, 6.

1978 Acanthaulax senta Drugg, p. 62, pl. 3, fig. 13, pl. 4, figs 1-3.

1980 Acanthaulax senta Woollam, pl. 3, fig. 3.

1980 Acanthaulax senta Bjærke, p. 150, pl. 3, figs 1-4.

1982 Acanthaulax areolata Riley \& Fenton, p. 199.

1983 Acanthaulax senta Woollam \& Riding, p. 3, pl. 4, figs 5, 6.

1984 Acanthaulax senta Riding, pl. 3, figs 6, 9.

1985 Acanthaulax areolata Lund \& Pedersen, p. 384, pl. 8, fig. 3.

1985 Acanthaulax scarburghensis Lentin \& Williams, p. 2.

1986 Liesbergia scarburghensis Berger, p. 343, fig. 5: 12.

Remarks. This species was originally introduced as Gonyaulax areolata by Sarjeant (1961). It was subsequently given the name Gonyaulacysta scarburghense by Sarjeant (1964, pp. 472-473). According to Lentin \& Williams (1985) G. areolata was a junior homonym, which is illegitimate (International Code of Botanical Nomenclature Art. 6.4; Art. 64.1) and had to be replaced by a validly published nom. nov., i.e. G. scarburghense. This nom. nov. is the oldest legitimate name (Art. 6.3). Riley \& Fenton (1982, p. 199) made an illegitimate transfer of this species to Acanthaulax Sarjeant, 1968 by using the junior homonym ( $G$. areolata), thus failing to conform to the rule that the oldest legitimate species name is transferred to a new generic name (Lentin \& Williams, 1985). Following the I. C. B. N. Art. 55 this species was transfered to the genus Acanthaulax as $A$. scarburghensis by Lentin \& Williams (1985).

Riley \& Fenton (1982, p. 119) and Woollam \& Riding (1983, p. 3) stated that Acanthaulax senta Drugg, 1978 may be conspecific with Gonyaulacysta scarburghense Sarjeant, 1964. Berger (1986, p. 343) confirmed that $A$. senta and $G$. scarburghense are synonymous and subsequently transferred this species to the genus Liesbergia Berger, 1986. According to Berger (1986, p. 341) the genus Liesbergia can be distinguished from Acanthaulax in "having a very characteristic apical horn which is only formed by a development of the external ornamentation and not by the entire periphragm as in Acanthaulax". 
Genus Atopodinium Drugg, 1978

Type species. Atopodinium prostatum Drugg, 1978

\section{Atopodinium prostatum Drugg, 1978}

Fig. 10F

1978 Atopodinium prostatum Drugg, p. 63, pl. 1, figs 1-7, text figs 1A-D.

1978 Dinoflagellate type 4, Thusu, pl. 7, figs 12,13 .

1985 Atopodinium prostatum Herngreen, pl. 2, fig. 1.

1985 Atopodinium prostatum Lund \& Pedersen, p. 382, pl. 7, fig. 2.

1985 Atopodinium prostatum Riding et al., pl. IV, fig. 8.

Remarks. Several of the specimens observed have less well developed protruding sack-like lobes at the antapex than the specimens illustrated by Drugg (1978, pl. 1, figs 1-7), and a few specimens seem more or less to lack such features. This is also observed among specimens recorded from Kong Karls Land, Svalbard (Thusu, 1978; Smelror, in press), and the Canadian Arctic (E. H. Davies, personal communication 1986). Both forms with extremely developed protruding sack-like lobes, and those completely lacking such features, are here regarded as end members of the species-complex $A$. prostatum.

\section{Genus Rigaudella Below, 1983}

Type species. Rigaudella aemula (Deflandre) Below, 1982.

\section{Rigaudella aemula (Deflandre) Below, 1982}

Fig. 10A

1938 Hystrichosphaeridium aemulum Deflandre, p. 688, fig. 6.

1947 Cannosphaeropsis aemula Deflandre, p. 19, fig. 5.

1960 Cannosphaeropsis paucispina Klement, p. 72, pl. 10, figs 9, 10

1969 Adnatosphaeridium aemulum Williams \& Downie, p. 17.

1982 Rigaudella aemula Below, pp. 139-140, 143-144, 146, figs 1-6, $16,17,18-21,22-23,24$ (pars.). (With detailed synonymy list.)

Remarks. As noted by Below (1982) there is a gradational transition between $R$. aemula and specimens which are described as Rigaudella filamentosa (Cookson \& Eisenack) Below, 1982. Both forms are known from Middle and Upper Jurassic strata elsewhere in North-West Europe (Sarjeant, 1979). Since the species appear to have nearly equivalent stratigraphic ranges, no attempt has been made to separate these two forms during the present study. Consequently, several specimens which may fit the description of $R$. filamentosa may here have been recorded as $R$. aemula. 


\section{List of recorded acritarchs, dinoflagellate cysts and tasmanitids}

Representative specimens are illustrated in figs 10-12

Ambonosphaera calloviana Fensome, 1979

Atopodinium prostatum Drugg, 1978

Caddasphaera halosa (Filatoff) Fenton, Neves \& Piel, 1980

Cassiculosphaeridia dictydia (Sarjeant) Riley \& Fenton, 1982

Chlamydophorella ectotabulata Smelror, in press

Chytroeisphaeridia cerastes Davey, 1979

Chytroeisphaeridia chytroeides (Sarjeant)

Downie \& Sarjeant, 1965

Chytroeisphaeridia grossa sp. nov.

Cleistosphaeridium ehrenbergii (Deflandre)

Davey et al., 1969

Cleistophaeridium polytrichum (Valensi)

Davey et al., 1969

Crussolia deflandrei Wolfard \& Van Erve, 1981

Ctenidodinium continuum Gocht, 1970

Ctenidodinium ornatum (Eisenack) Deflandre, 1939

Diacanthum filapicatum (Gocht) Stover \& Evitt, 1978

Ellipsoidictyum cinctum Klement, 1960

Endoscrinium galeritum (Deflandre) Vozzhennikova, 1967

Escharisphaeridia laevigata sp. nov.

Escharisphaeridia pocockii (Sarjeant) Erkmen \& Sarjeant, 1980

Fromea tornatilis (Drugg) Lentin \& Williams, 1981

Gonyaulacysta birkelundii Fensome, 1979

Gonyaulacysta jurassica (Deflandre) Norris \& Sarjeant, 1965

Gonyaulacysta jurassica longicornis

(Deflandre) Sarjeant, 1982

Heslertonia teichophera (Sarjeant) Sarjeant, 1976

? Hystrichodinium lanceatum Davies, 1983

Hystrichogonyaulax pectinigera (Gocht) Stover \& Evitt, 1978

Kylindrocysta spinosa Fenton et al., 1980

Lacrymodinium warrenii Albert, Evitt \& Stein, 1986

Liesbergia scarburghensis (Sarjeant) Berger, 1986

Lithodinia jurassica Eisenack, 1935

Meiourogonyaulax deflandrei Sarjeant, 1968
Meiourogonyaulax callomonii Sarjeant, 1972

Meiourogonyaulax strongyla Sarjeant, 1972

Mendicodinium groenlandicum (Pocock \&

Sarjeant) Davey, 1979

Micrhystridium brevispinosum Valensi, 1953

Micrhystridium fragile Deflandre, 1947

Micrhystridium recurvatum Valensi, 1953

Nannoceratopsis pellucida Deflandre, 1938

Occisucysta thulia Davies, 1983

Pareodinia alaskensis Wiggins, 1975

Pareodinia brachythelis Fensome, 1979

Pareodinia ceratophora Deflandre, 1947

Pareodinia prolongata Sarjeant, 1959

Pareodinia wigginsii Smelror, in press

Pleurozonaria sp.

Pluriarvalium osmingtonense Sarjeant, 1962

Prolixosphaeridium granulosum (Deflandre)

Davey et al., 1966

Pterospermopsis sp. A of Fensome, 1979

Rhynchodiniopsis cladophora (Deflandre) Below, 1981

Rigaudella aemula (Deflandre) Below, 1982

Scriniodinium oxfordianum Sarjeant, 1962

Sentusidinium asymmetrum (Fenton et al.)

Lentin \& Williams, 1981

Sentusidinium baculatum (Dodekova) Sarjeant \& Stover, 1978

Sentusidinium pelionense Fensome, 1979

Sentusidinium rioultii (Sarjeant) Sarjeant \&

Stover, 1978

Sentusidinium verrucosum Wiggins, 1973

Sentusidinium sp. B of Fensome, 1979

Sirmiodinium grossii Alberti, 1961

Solisphaeridium ankyleton Fensome, 1979

Susadinium? sp. A of Smelror, 1987

Tasmanites tardus Eisenack, 1958

Tubotuberella eisenackii (Deflandre) Stover \&

Evitt, 1978

Tubotuberella lurida (Deflandre) Davies, 1983

Valensiella ampulla Gocht, 1970

Valensiella ovula (Deflandre) Eisenack, 1963

Valensiella vermiculata Gocht, 1970

Veryhachium sortehatense Fensome, 1979

Wanaea digitata Cookson \& Eisenack, 1958

Wanaea fimbriata Sarjeant, 1961

Wanaea thysanota Woollam, 1982

Xylochoarion hacknessense Erkmen \&

Sarjeant, 1978 

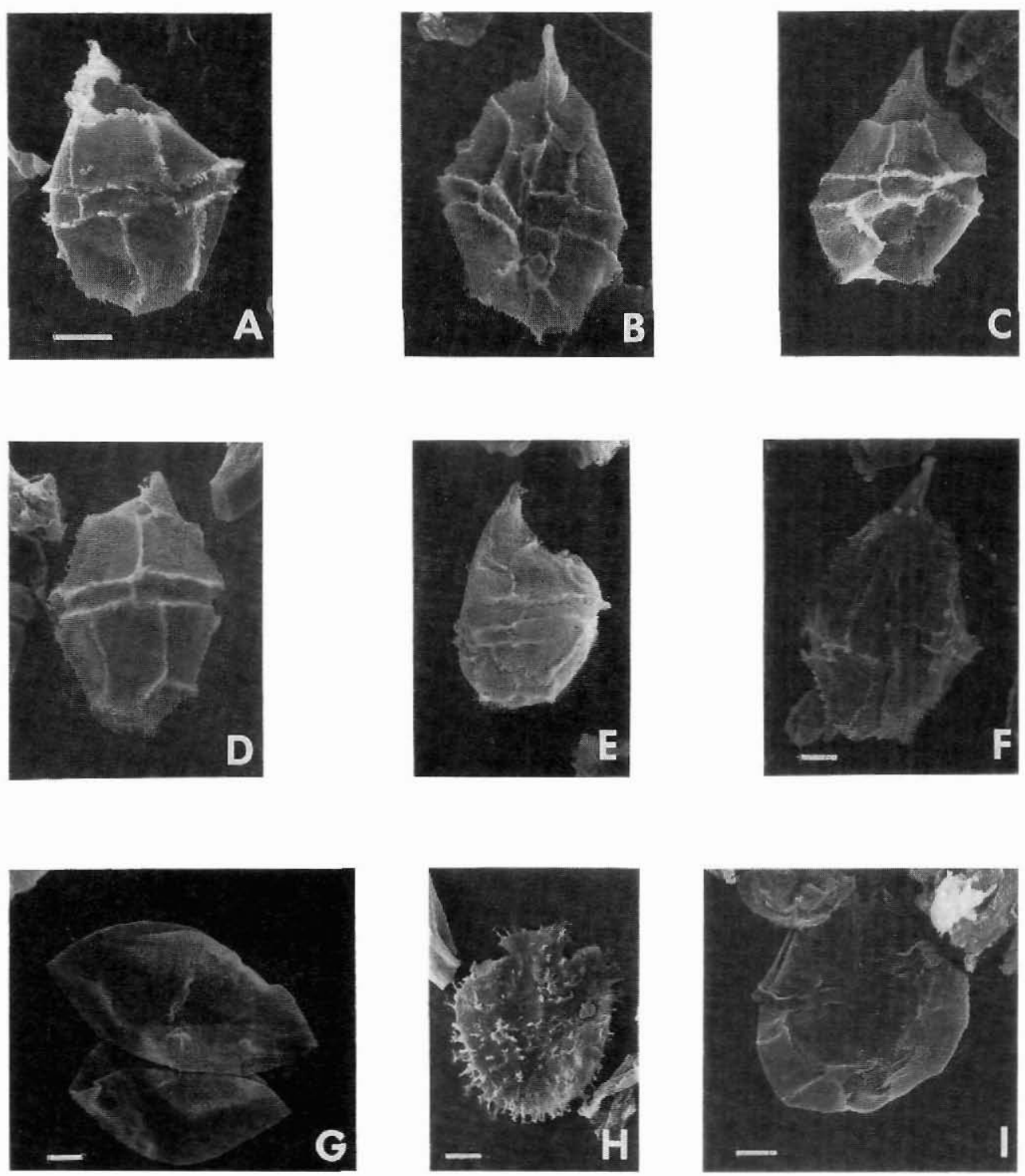

Fig. 11. Upper Middle and lower Upper Jurassic dinoflagellate cysts from East Greenland. Scale bars represent $10 \mu \mathrm{m}$ in all figures. Figs A-E all same magnification.

A-E: Lacrymodinium warrenii Albert, Evitt \& Stein, 1986. SEM: MGUH 18.627-31, GGU sample 139156.

F: Gonyaulacysta jurassica (Deflandre) Norris \& Sarjeant, 1965. SEM: MGUH 18.632, GGU sample 245977.

G: Mendicodinium groenlandicum (Pocock \& Sarjeant) Davey, 1979. SEM: MGUH 18.633, GGU sample 245977.

H: Sentusidinium rioultii (Sarjeant) Sarjeant \& Stover, 1978. SEM: MGUH 18.634, GGU sample 245967.

I: Sirmiodinium grossii Alberti, 1961. SEM: MGUH 18.635, GGU sample 245967. 

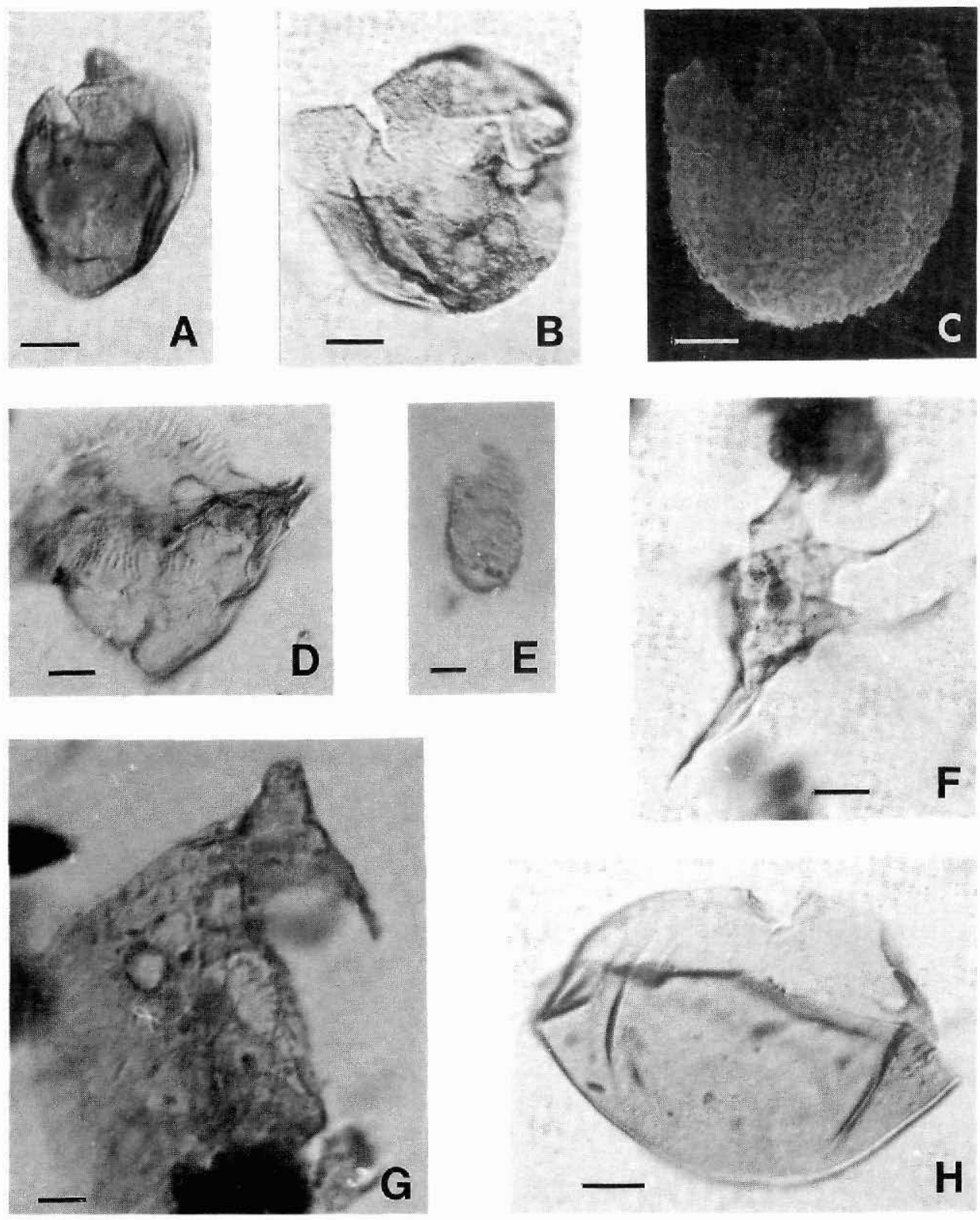

Fig. 12. Upper Middle and lower Upper Jurassic dinoflagellate cysts and acritarchs from East Greenland. Scale bars represent $10 \mu \mathrm{m}$ in all figures.

A: Pareodinia brachythelis Fensome, 1979. MGUH 18.636, GGU sample 185635, F34/2.

B: Escharisphaeridia pocockii (Sarjeant) Erkmen \& Sarjeant, 1980. MGUH 18.637, GGU sample 185635, G41/0.

C: ?Sentusidinium sp. SEM: MGUH 18.638, GGU sample 139156.

D: Wanaea thysanota Woollam, 1982. MGUH 18.639, GGU sample 245981, 040/2.

E: Kylindrocysta spinosa Fenton, Neves \& Piel 1980. MGUH 18.640, GGU sample 139197, C32/0.

F: Veryhachium sortehatense Fensome, 1979. MGUH 18.641, GGU sample 185639, M35/0.

G: Occisucysta thulia Davies, 1983. MGUH 18.642, GGU sample 185642, E35/3.

H: Mendicodinium groenlandicum (Pocock \& Sarjeant) Davey, 1979. MGUH 18.643, GGU sample $185700, \mathrm{~K} 35 / 2$. 
Acknowledgements. Samples were made available by S. Piasecki, GGU. The author acknowledges the kind permission of the Director, Grønlands Geologiske Undersøgelse to publish data from the study of that material. He is further indebted to S. Piasecki (GGU) for his comments on the submitted manuscript, to U. M. Wang (IKU) for processing the samples, I. L. S. Berg (IKU) for making the illustrations and to E. M. Solberg (IKU) for typing the manuscript. Type and figured specimens (MGUH prefix) are deposited in the Geological Museum, Copenhagen, Denmark.

\section{References}

Below, R. 1982: Rigaudella, ein neues Genus von Dinoflagellaten Zysten. Neues Jb. Geol. Paläont. Mh. 1982, 137-150.

Berger, J.-P. 1986: Dinoflagellates of the Callovian - Oxfordian boundary of the 'Liesberg-Dorf' quarry (Berner Jura, Switzerland). Neues Jb. Geol. Palaont. Abh. 172, 331-355.

Callomon, J. H. \& Birkelund, T. 1980: The Jurassic transgression and the mid-late Jurassic succession in Milne Land, central East Greenland. Geol. Mag. 117, 211-226.

Davey, R. J. 1979: A re-appraisal of the genus Chytroeisphaeridia Sarjeant 1962. Palynology 3, 209-218.

Davey, R. J. \& Riley, L. A. 1978: Late and Middle Jurassic dinoflagellate cysts. In Thusu, B. (edit.) Distribution of biostratigraphically diagnostic dinoflagellate cysts and miospores from the Northwest European continental shelf and adjacent areas. Continental Shelf Inst. Publ. 100, 31-45.

Drugg, W. S. 1978: Some Jurassic dinoflagellate cysts from England, France and Germany. Palaeontographica, Abt. B, 168, 61-79.

Fensome R. A. 1979: Dinoflagellate cysts and acritarchs from the Middle and Upper Jurassic of Jameson Land, East Greenland. Bull. Gronlands geol. Unders. 132, 98 pp.

Fenton, J. P. G., Neves, R. \& Piel K. M. 1980: Dinoflagellate cysts and acritarchs from Upper Bajocian to Middle Bathonian strata of central and southern England. Palaeontology 23, 151-170.

Herngreen, G. F. W. \& Boer, K. F. de. 1978: Dinoflagellate zonation of Upper Dogger and ?lowermost Malm in the Netherlands. Palinol. núm. extraord. 1, 283-291.

Herngreen, G. F. W., Boer, K. F. de., Romein, B. J., Lissenberg, Th. \& Wijker, N. C. 1983: Middle Callovian beds in the Achterhoek, Eastern Netherland. Meded. Rijks Geol. Dienst 37-3, 95-123.

Lentin, J. K. \& Williams G. L. 1985: Fossil dinoflagellates: Index to genera and species, 1985 edition. Can. Tech. Rep. Hydrogr. Ocean Sci. 60, 451 pp.

Lund, J. J. \& Pedersen, K. R. 1985: Palynology of the marine Jurassic formations in the Vardekløft ravine, Jameson Land, East Greenland. Bull. geol. Soc. Denmark 33, 371-399.

Piasecki, S. 1980: Middle to Late Jurassic dinoflagellate cyst stratigraphy from Milne Land and Jameson Land (East Greenland) correlated with ammonite stratigraphy. Unpubl. thesis, Univ. Copenhagen, $167 \mathrm{pp}$.

Poulsen, N. E. 1985: Dinocyststratigrafien i den nedre del af Hareelv Formation (Øvre Jura), Jameson Land, Østgrønland. Dansk geol. Foren. Årsskr. 1984, 133-137.

Raynaud, J. F. 1978: Principaux dinoflagelles characteristiques du Jurassique supérieur d'Europe du Nord. Palinol. núm. extraord. 1, 387-405.

Riding, J. B., Penn, I. E. \& Woollam, R. 1985: Dinoflagellate cysts from the type area of the Bathonian Stage (Middle Jurassic, Southwest England). Rev. Palaeobot. Palynol. 45, 149-169.

Riley, L. A. \& Fenton, J. P. G. 1982: A dinocyst zonation for the Callovian to Middle Oxfordian succession (Jurassic) of Northwest Europe. Palynology 6, 193-202.

Sarjeant, W. A. S. 1961: Microplankton from the Kellaways Rock and Oxford Clay of Yorkshire. Palaeontology 4, 90-118.

Sarjeant, W. A. S. 1964: New name and diagnosis for an Upper Jurassic species of Gonyaulacysta (Dinophyceae). Palaeontology 7, 472-473. 
Sarjeant, W. A. S. 1972: Dinoflagellate cysts and acritarchs from the Upper Vardekløft Formation (Jurassic) of Jameson Land, East Greenland. Meddr Grønland 195(4), 65 pp.

Sarjeant, W. A. S. 1979: Middle and Upper Jurassic dinoflagellate cysts: The world excluding North America. Am. Assoc. strat. Palynol. Contr. Ser. 5B, 133-157.

Smelror, M. in press: Late Bathonian to Early Oxfordian dinoflagellate cysts and acritarchs from Kong Karls Land, Svalbard. Rev. Palaeobot. Palynol. 56.

Surlyk, F. 1977: Stratigraphy, tectonics and palaeogeography of the Jurassic sediments of the areas north of Kong Oscars Fjord, East Greenland. Bull. Grønlands Geol. Unders. 123, 56 pp.

Surlyk, F. 1978: Jurassic basin evolution of East Greenland. Nature 274, 130-133.

Surlyk, F., Callomon, J. H., Bromley, R. G. \& Birkelund, T. 1973: Stratigraphy of the Jurassic-Lower Cretaceous sediments of Jameson Land and Scoresby Land, East Greenland. Meddr Grønland 193(5) (also Bull. Grønlands geol. Unders. 105), $76 \mathrm{pp}$.

Surlyk, F. \& Zakharov, V. A. 1982: Buchiid bivalves from the Upper Jurassic and Lower Cretaceous of East Greenland. Palaeontology 25, 727-753.

Thusu, B. 1978: Aptian to Toarcian dinoflagellate cysts from Arctic Norway. In Thusu, B. (edit.): Distribution of biostratigraphically diagnostic dinoflagellate cysts and miospores from the Northwest European continental shelf and adjacent areas. Continental Shelf Inst. Publ. 100, 61-95.

Williams, G. L. \& Downie, C. 1969: Generic re-allocations. In Davey, R. J., Downie, C., Sarjeant, W. A. S. \& Williams, G. L. Appendix to studies on Mesozoic and Cainozoic dinoflagellate cysts. Bull. Brit. Mus. (Nat. Hist.) Geol. Appendix to Suppl. 3, 17 (only).

Woollam, R. 1980: Jurassic dinocysts from shallow marine deposits of the East Midlands, England. $J$. Univ. Sheffield Geol. Soc. 7.5, 243-261.

Woollam, R. \& Riding, J. B. 1983: Dinoflagellate cyst zonation of the English Jurassic. Rep. Inst. Geol. Sci. 83/2, $42 \mathrm{pp}$. 